\title{
POLICIES FOR BUILDING A FUNCTIONING LABOUR MARKET IN BULGARIA
}

\author{
Venelin Terziev
}

Academician of the Russian Academy of Natural History, Moscow, Russia, Prof. D.Sc. (Ec.), D.Sc. (National Security), D.Sc. (Social Activities), Ph.D., National Military University, Veliko Tarnovo, Bulgaria; University of Rousse, Rousse, Bulgaria, terziev@skmat.com

\begin{abstract}
The reduction of the share of industry in creating GDP and in aggregate employment is a natural process which marks the transition from industrial to information society. This cardinal change in the structure of national economies is often accompanied by a radical change in the professional careers of employed people, a rise in unemployment and poverty and exacerbation of social conflicts. The transition from industrial production to the development of different types of services is difficult and often has a high cost.
\end{abstract}

Keywords: labour market, employment, unemployment, social policies.

\section{INTRODUCTION}

The reduction of the share of industry in creating GDP and in aggregate employment is a natural process which marks the transition from industrial to in-formation society. This cardinal change in the structure of national economies is often accompanied by a radical change in the professional careers of employed people, a rise in unemployment and poverty and exacerbation of social conflicts. The transition from industrial production to the development of different types of services is difficult and often has a high cost.

The deindustrialization in Bulgaria has a number of specifics. Com-pared to Western economies, it was determined not so much by the natural course of economic development but rather by the initiated political changes and the policy of reforms for the transition to a market economy. Thus, the deindus-trialization processes had to solve both economic and political tasks: the econo - my had to become efficient and competitive, but along with that, and because of that, it had to change its ownership, size and characteristics. The reforms began with the change of ownership, the restriction of monopoly and environmental pollution, the eradication and limitation of inefficient industries, and it continued to the establishment of a functioning market economy, corresponding to the standards and rules of the EU policy and the requirements of the globalizing economy. These two essentially transitional periods - to a market economy and to the EU integration - led to a radical restructuring of production and employ-ment. Unlike in other countries in Central and Eastern Europe going through similar transitions, in Bulgaria these processes had a high social cost and 
a sig-nificant impact on the incomes of the population, its security and employment (Georgiev, 2016; Georgiev, 2017-a).

\section{POLICIES FOR BUILDING A FUNCTIONING LABOUR MARKET}

The institutions and legislation related to the labour market were created at the beginning of the transition and this gave the opportunity to have them developed in accordance with the existing ones in the European Union countries.

A special government decree (Decree №57 of the end of 1998) was adopted at the outset of the transition and the advent of the first groups of unemployed, which regulates the establishment of employment services and cash payments in case of unemployment - benefits (for the insured) and social benefits (for those with no insurance, mainly the ones graduating from secondary and university education institutions, with vocational training and registering as unemployed in employment services). This regulation, which has been changed (supplemented, amended or elaborated), gave rise to conditions for:

- Registration of unemployed and others seeking employment and of the vacancies from employers;

- Payment of cash benefits to employees dismissed not because of their fault, but on the initiative of employers and mainly due to full or partial liquidation of enterprises, structural changes, cuts in the number, or expiration of the employment contract;

- Payment of cash benefits to registered unemployed who graduated from secondary schools and universities, with vocational training, registered in public employment services (employment agencies);

- Training, career guidance and retraining of employees dismissed from the organizations. This training was organized by labour offices at the expense of the special fund 'Professional Qualification and Unemployment' ('PQU' Fund) aiming at the more rapid return of the unemployed to work;

- The development of a state system for organizing mediation, retraining, registration, payment of benefits and unemployment benefits, implementation of state employment policy and regulation of the labour market - National Employment Service at the Ministry of Labour and Social Affairs, which includes the central management, 9 regional offices and labour offices (some of them with branches) in all district centres and larger towns and settlements in the country;

- The formation of a special fund for the unemployed - for the payment of cash benefits in case of unemployment, recruitment mediation, training and other active employment measures - the PQU Fund whose source is the monthly contributions of employers from the business sector and the state budget.

Essentially there are two contradictory trends in the developed and functioning state of the Employment Agency - the decentralization of most of the functions and at the same time centralization of administration regarding the provision of resources for the various institutional levels in the labour market, the development of strategies and active employment policy, etc.

The role of a main mediator in the labour market is assigned to labour offices. Over the past years their functions have evolved, their priorities have enriched and changed. In the early years, they mainly carried out functions of registration of unemployed, announcing vacancies to them and paying cash benefits and benefits to the unemployed. These activities of the so-called 'passive policy' occupied over $90-95 \%$ of the work of labour offices. And still today, although much less, there are labour offices for which these functions are the main or sole ones. Unemployed still get registered in labour offices mainly because of the opportunity to receive benefits or unemployment benefits. In support of this claim is the data for the relatively mass refusal of the unemployed to retain their monthly registration at labour offices after the expiry of the term for receipt of these cash payment. This means that the unemployed do not trust and do not expect that by using public employment services they would return to work.

In public employment services there has been a gradual development of the so- called 'active' employment policy (18):

- Recruitment mediation including information on vacancies and work conditions, vocational guidance, motivation and professional qualification with the purpose of getting jobless people employed in the available jobs on the market;

- Promotion of self-employment and entrepreneurship of the unemployed;

- Implementation of programmes and other measures of the state policy for regulation of the labour market;

- Performance of specialized control over the observance of laws and other normative documents in the 
field of unemployment insurance, payment of cash benefits and compensations, use of the provided incentives for hiring unemployed for the purpose intended, entrepreneurship, etc.

Passive policy measures prevailed during the first years of the labour market creation. The share of the costs of this policy varied from $93.7 \%$ (1991) to $68 \%$ (1999). The majority of the measures were in the form of unemployment benefits paid only to the people dismissed. At first, their size was generously determined and depended on the remuneration received by then, and the period of receipt of the benefits was the same for all. Very soon, another more restrictive system was introduced.

The policies were oriented more towards labour supply and less towards labour demand (19). Dominating were passive policy measures: payment of benefits and social benefits for certain groups of unemployed, encouraging early retirement and withdrawal from the labour market of part of the working age population. The number of the people who continued their education increased; there was also considerable external migration, which reduced the supply of labour.

There was a lack of purposeful state policy for employment restructuring. Significant development was given to the social policy and the passive policy for the labour market, with adverse long-term consequences for the economic activity of certain groups of the population.

The deindustrialization resulted in the implementation of sector-focused employment programmes - for qualification and employment of the massively dismissed workers from restructuring or closing inefficient industries (ore mining and coal mining, steel industry, etc.).

Since the late 1990s, and especially since the beginning of the new millennium, there has been a change in the strategy on labour supply - from passive to active measures; from social benefits to employment; from individual measures and programmes to national action plans in favour of employment.

The employment policy got included in the macroeconomic and regional policy. There emerged the understanding that employment policy is rather an economic than a social problem and that the solution to the problems of high unemployment and poverty is in the economic and not in the social policy, social benefits and temporary subsidized employment. The employment policies started to become more regional. There appeared more programmes that reflected the socioeconomic priorities of the regions.

Business promotion and mitigation of social problems are among the main guidelines. The actions are aimed at:

- Supporting the establishment and operation of small and medium-sized enterprises, particularly in the regions in need of diversification of the economic structure (regions of industrial decline, underdeveloped rural areas);

- Projects for employment and restructuring of manufacturing plants, mainly in regions with high unemployment and risk of exacerbation of social problems;

- Creation of entrepreneurial and innovative environment (establishment of networking cooperation, regional marketing and dissemination of information, support to the creation and operation of market and technological infrastructure, business services, improving the quality of human resources, improving the quality of the environment as a general condition for increasing the investment attractiveness, etc.).

The programmes with a focus on infrastructure sites are aimed at the reintegration of unemployed and have a positive impact on the development of municipalities.

The total effect of the transition from a planned-distributive to a market system in key economic areas such as changing the form of ownership through the privatization or transformation of the financial system from state to mixed (establishing a system of commercial banks, commodity and other exchanges, etc.) seems relatively transparent today. The area related to labour relations remains more diffuse. It is generally accepted that an economic planning and distribution system inherently denies the existence of market regulators of labour processes. At first glance, it is true.

In the planning and distribution system one of the fundamental public relations - the right of labour - is interpreted as an obligation of people to engage in socially useful labour. In contrast, in a market economy voluntary labour is fundamental - the right of people to choose freely between self-employment and voluntary unemployment without coercion.

In the two systems, the state's role in providing employment is determined in a different way. If, in the first case, in response to the binding nature of labour, the state declares a guaranteed provision of work to its nationals, in the second case, by virtue of the different distribution of rights and responsibilities between the nationals and the society, there is no such guaranteed obligation in respect to every person. If the planning 
system based on state ownership involves the regulation of wages centralized through a unified tariff network or system, in the market economy operate more complex mechanisms that involve wage determination by the labour market, through a developed system of collective contracting (but not in all countries), a legislative determination of the minimum wage, limiting wage growth in order to curb inflation, etc.

The planning system also uses its immanent instruments to influence the supply and demand of labour, the regulation of hiring and dismissal of workers. Among these tools are: statutory limits on numbers, rules for determining the wage, the ratio between wage growth and labour productivity, a progressive tax on wage growth, paying for labour resources, the address registration institute, planned distribution of university graduates, agricultural migration, organized borrowing of employees, etc. Such tools are not characteristic of the market economy.

However, despite the quality differences, the staunch opposition is not always fair. The constitutional obligation of people to work, for example, was combined with the free choice of profession. In the search of a job employees had the right to (with certain restrictions, related, for example, to the place of residence) to communicate freely with employers. In turn, employers had relative freedom in choosing the needed employee (within, for example, the staff listing and the settlement). Employees had the right to leave of their own free will, which is more characteristic of the nature of a market economy. Generally, the freedom of movement of employees from one enterprise to another was not restricted. If tariff rates were determined at a central level, within the established systems of labour remuneration, non-cash income (company housing) turned into a factor of market differentiation. These and many other facts are evidence of the presence of elements of market labour relations in the planning and distribution system, characteristic of Bulgaria.

Perhaps the main difference between the two systems, raised years ago to the rank of a political advantage for the planned economy, is the absence of open unemployment. Since it was believed that full employment was achieved, there was no policy on unemployment. The main task of the state was to maintain full employment and its rationalization. This policy direction was determined as employment policy. Given that the chronic problem of the Bulgarian economy was not unemployment, but the deficit of personnel, the senior management considered the provision of workforce for the national economy as a main economic objective of the employment policy.

However, in the 1970s and 1980s there was an observed retreat from the pure planning system. Problems, connected not with the shortage of staff, but with the possible deficit of jobs were indirectly recognized. Thus, for example, one of the main tasks of a number of decrees and regulations was related to an improvement in the organization of wages and introduction of new tariff rates and wages for the workers in the productive sectors of the national economy and in achieving a better balance between the number of jobs and the number of employees. This expanded the degree of freedom of employers to dismiss workers for economic reasons. The possible occurrence of unemployment forced the taking of such decisions (as temporary rules) on the procedure for recruitment and retraining of workers exempt from associations, businesses and organizations, as well as to ensure effective employment of the population, improvement of the employment system and increase in the social guarantees for workers.

However, these and other changes took place within the existing political and economic paradigm. Its change at the beginning of the reforms in the 1990s questioned the basic steps of the transition and the features of the transitional period itself (Terziev, 2019a-k).

Perhaps the transition related to the return of democratic civil rights turned out to be the least dramatic. The Act on Protection against Unemployment and Employment Promotion of 1997, and before that the new Constitution of the Republic of Bulgaria adopted in 1991, gave the statutory right of citizens to self-administer their ability to work without any coercion. But in an economic aspect this transformation turned out to be much more dramatic. On the one hand, many workers remained 'attached' to the companies through different non-monetary levers (housing, kindergartens, etc.), with the preserved institute of address registration, the absence of housing market, etc. Job loss or change meant also loss of significant social benefits. On the other hand, the redistribution of economic responsibility between citizens and the state led to the irrelevance of the state's obligation to ensure the provision of jobs for its citizens. The latter became impossible due to the levelling of the balance of the rights and the obligations of employees and employers. Unlike within the previous centralized system, the state lost its right to dictate the conditions of employment for people in need of work (through mechanisms of non-economic coercion) to the increasing range of privatized enterprises. The shrunk public sector of the economy, on which the state could have a direct influence (e.g. by increasing the jobs in the civil service), had its limitations and by volume it could not accumulate all who lost their jobs. But, if the legislative recognition of the new relations required minimum time, the formation of new institutions and instruments to support employment, offsetting to some extent the 
old ones, could not be achieved so quickly. As a result of such transformations, inequality arose in the labour market. Graduates, persons returning from places of detention, women trying to return to work after maternity leave due to pregnancy and childbirth and many other groups of citizens found themselves in a more disadvantaged position in the labour market. Inadequate tools or lack of tools for their support and their return to employment, implemented in the market economy, brought back the attitude to the state as to an institute obliged to provide guaranteed employment. But an answer to the question where these people could be employed is rarely found (Terziev, 2019a-k) .

Another consequence of the democratic changes in the labour law in the transitional period was the increase of discrimination in recruitment and dismissal. But, as in the previous case, these processes were caused not only by the nature of the labour market, but rather by the transition state, where the area of traditional state control over the compliance with the labour rights of citizens narrowed and new tools and institutes (institutions) had not yet been created or were not working effectively enough.

The transformation of the Bulgarian economy into a market one revealed numerous peculiarities and paradoxes in the formation of the labour market, which are not usually characteristic of the countries with a traditional organization of the market economy. Thus, the absence of major economic growth in the first years of the reforms contributed to the establishment of a view of the uniqueness of the Bulgarian transition phase in the sense that the successfully selected macroeconomic strategy resulted in the avoidance of serious problems in the labour market. This 'success' however was accompanied by hypertrophic appearance of intermediate forms in the status of the employees who were not completely unemployed, but were also not working. 'Unemployment in the workplace', including the one connected with the preservation of excessive, economically unjustified employment, paradoxically coupled with a shortage of staff. The actual unemployment resulting from a periodic change of jobs met the inflexible employment system, the weak points of the labour market, the insufficient understanding of the role of some market mechanisms such as the employment services (primarily with their functions in informing about available vacancies and workers seeking employment). Structural unemployment, usually determined by the recession in some industry branches and the growth (including the increase in the number of jobs) in new sectors is generally eliminated by systems of retraining for employees. But in the transition conditions of Bulgaria, the compensating creation of new jobs was clearly insufficient, and the new jobs often required no training but professional habits and skills of a lower level than the ones in the previous job. The following measures for the recovery of aggregate demand (or for retention of its decline), promotion of job creation (tax concessions, removing the obstacles to the creation of small businesses, the provision of know-how, etc.) and promotion of part-time employment are often used in response to cyclical unemployment (unemployment of insufficient demand). But in Bulgarian transitional conditions, cyclical unemployment rather took the form of systematic unemployment as a result of the continuous and prolonged economic recession, sectoral imbalances and other causes that put into question the traditional means of counteracting to unemployment.

Similar paradoxes of the labour relations in an economy in transition often suggest that the measures of state influence on the labour market make no sense in such a situation. Therefore, their application should be postponed until the moment when the labour market and the economic system as a whole finally acquires classic 'market' features. But the problem is that not only the listed, but also many other paradoxes of the transitional period entirely dictate the situation in the labour market. The increasing discrimination in hiring and dismissal, for example, can hardly be attributed to the regularities of the transition. Even the distortions related to the causes of unemployment cannot be used to deny the fact that each year tens of hundreds of people change their jobs remaining in a state of frictional unemployment for a certain period of time. Structural changes, although acquiring the form of almost universal, but uneven decline, coexist with different points of growth both in new sectors (e.g. financial and commercial sector) and within the industries that are experiencing recession (some companies hire new workers and others dismiss workers). The weak points of the institutions in the labour market, regulating the wage dynamics (e.g. employment contracts and agreements) cannot also be used as a starting point for conclusions about their temporary inappropriateness. Nowadays, the transformation of the labour relations from such that are typical of the planning economy to ones typical of the market economy is significantly delayed, compared with the advent of other attributes of the market (formation of different forms of ownership, financial and other markets).

It seems that one of the main differences in the regulation of the processes connected with the employment of the population in a planning and market economy is the unacceptability (to a large degree) of the linear management dependences, characteristic of the previous economic system, in the new conditions. The relations between the state (guaranteeing a job for everybody) and employees (bound by the state to work) were replaced by more subtle and complex relations, free from such a direct dependence (it is required to maintain employment while respecting the right of people to work or not work and the right of employers to hire only the needed workers in the right amount). Furthermore, the state is no longer the sole participant in 
the labour market policy. The role of employers (through their associations) and employees (through trade unions) is increased. There is a change in the distribution of competencies between government bodies. In place of the state planning system (such as the Planning Ministry or Committee) as the primary institute for planning the distribution of labour resources is established a new division of labour between government structures that have an impact on the processes of generation, distribution and utilization of workforce. This division of labour is impossible without a proper division of responsibility within a unified state employment strategy. Such a strategy is a targeted image of the employment arrangement and a kind of a set of actions in different areas (finance, taxation, employment relations, income, education, labour market, etc.), which are implemented by legislative and executive state bodies and are aimed at non- inflationary achievement of full, freely chosen and productive employment.

Thus, one of the areas of influence on the state of employment and unemployment, whose role remains undervalued to this day, is related to the policy of the state on the labour market. The nowadays existing variety of interpretations of the term „labour market", the influence of the state on it, but also of the factors that directly or indirectly affect its condition and functioning, are also a reflection of the state of transition (Terziev, Kanev, 2019; Terziev, 2019a-k; Terziev, 2018-d; Terziev, Georgiev, 2018e-f; Terziev, Arabska, 2014; Terziev, 2015-b; Terziev, Arabska, 2016a).

\section{CONCLUSION}

The main conclusion that can be made is that the implementation of special employment programmes is one of the alternative solutions for reducing the tensions in the labour market. Their implementation, together with local regional initiatives and programmes, has the potential to increase employment and reduce unemployment.

To sum up, the restructuring of the economy continues and the efforts should be directed at improving its efficiency and competitiveness, as well as at limiting the budget sector and especially the increase in its capacity. Employment policies can increase their capacities if they become long-term and more closely linked to national and regional economic development plans (Terziev, 2019a-k).

\section{REFERENCE LIST}

Georgiev, Marin. (2016). Obshtestvenoto i ikonomichesko razvitie v konteksta na sotsialnite politiki. // Spisanie za nauka "Novo znanie“. Visshe Uchilishte po Agrobiznes i Razvitie na Regionite, 5, 2016, N 4, str. 26-41, ISSN 2367-4598 (Online), (Print) ISSN 1314-5703 (Георгиев, Марин. Общественото и икономическо развитие в контекста на социалните политики. // Списание за наука „Ново знание“. Висше училище по агробизнес и развитие на регионите, 5, 2016, N 4, стр. 26-41, ISSN 2367-4598 (Online), (Print) ISSN 1314-5703.

Georgiev, Marin. (2017). Sbalansirovannaya karta kak alyternativa malogo biznesa. // Innovatsionnie tehnologii v nauke novogo vrmeni, Sbornik statey Mezhdunarodnoy nauchno - prakticheskoy konferentsii 1 fevralya 2017 g., Ufa NITS AETERNA, Chasty 1, 2017, s. 43-49, ISBN 978-5-00109004-5, ISBN 978-5-00109-007-6 (Георгиев, Марин. Сбалансированная карта как альтернатива малого бизнеса. // Инновационніе технологии в науке нового врмени, Сборник статей Международной научно - практической конференции 1 февраля 2017 г., Уфа НИЦ АЭТЕРНА, Часть 1, 2017, с. 43-49, ISBN 978-5-00109-004-5, ISBN 978-5-00109-007-6).

Georgiev, Marin. (2017a). Impacts of active social programs on labor market. // Mezhdunarodnayy nauchnayy zhurnal „Innovatsionnaya nauka“. NITS Aeterna, N 02-1, 2017, pp. 139-143, ISSN 24106070 (Georgiev, Marin. Impacts of active social programs on labor market. // Международный научный журнал „Инновационная наука“. НИЦ Аэтерна, N 02-1, 2017, pp. 139-143, ISSN 24106070).

Terziev, V., Kanev, D. (2019). Modern developments in behavioral economics. // Smart Technologies and Innovations in Design for Control of Technological Processes and Objects: Economy and Production Proceeding of the International Science and Technology Conference „FarEastCon-2018” Volume 138, October 2-4, 2018, Vladivostok, Russian Federation, pp. 10-23, 2019, (Print) ISBN978-3-030-15576-6, (Online) ISBN978-3-030-15577-3.

Terziev, Venelin. (2019a). Provision of integrated employment and social assistance services in Bulgaria. // Smart Technologies and Innovations in Design for Control of Technological Processes and Objects: 
Economy and Production Proceeding of the International Science and Technology Conference „FarEastCon-2018” Volume 138, October 2-4, 2018, Vladivostok, Russian Federation, pp. 24-39, 2019, (Print) ISBN978-3-030-15576-6, (Online) ISBN978-3-030-15577-3.

Terziev, Venelin. (2019b). Problems of control in the social sphere. // INTCESS 2019- $6^{\text {th }}$ International Conference on Education and Social Sciences, 4-6 February, 2019, Dubai, International Organization Center of Academic Research, Istanbul, Turkey, pp. 577-593, ISBN: 978-605-82433-5-4.

Terziev, Venelin. (2019c). The criterion "competence" in the economic sector. // INTCESS 2019- $6^{\text {th }}$ International Conference on Education and Social Sciences, 4-6 February, 2019, Dubai, International Organization Center of Academic Research, Istanbul, Turkey, pp. 1241-1247, ISBN: 978-605-824335-4.

Terziev, Venelin. (2019d). Social policy and labor market development in Bulgarian transition period. // INTCESS 2019- $6^{\text {th }}$ International Conference on Education and Social Sciences, 4-6 February, 2019, Dubai, International Organization Center of Academic Research, Istanbul, Turkey, pp. 703-714, ISBN: 978-605-82433-5-4.

Terziev, Venelin. (2019e). Theoretical basis of development of labor market and social policy in the republic of Bulgaria. // INTCESS 2019- th $^{\text {th }}$ International Conference on Education and Social Sciences, 4-6 February, 2019, Dubai, International Organization Center of Academic Research, Istanbul, Turkey, pp. 715-726, ISBN: 978-605-82433-5-4.

Terziev, Venelin. (2019f). The problem of social efficiency- Indicators for social efficiency. // INTCESS 2019$6^{\text {th }}$ International Conference on Education and Social Sciences, 4-6 February, 2019, Dubai, International Organization Center of Academic Research, Istanbul, Turkey, pp. 669-678, ISBN: 978605-82433-5-4.

Terziev, Venelin. (2019g). Experiencing social policy development and efficiency measurment. // INTCESS 2019- $6^{\text {th }}$ International Conference on Education and Social Sciences, 4-6 February, 2019, Dubai, International Organization Center of Academic Research, Istanbul, Turkey, pp. 679-686, ISBN: 978605-82433-5-4.

Terziev, Venelin. (2019h). Efficiency and assessment of social technology. // INTCESS 2019- $6^{\text {th }}$ International Conference on Education and Social Sciences, 4-6 February, 2019, Dubai, International Organization Center of Academic Research, Istanbul, Turkey, pp. 687-694, ISBN: 978-605-82433-5-4.

Terziev, Venelin. (2019i). Conceptual framework of social adaptation. // INTCESS 2019- $6^{\text {th }}$ International Conference on Education and Social Sciences, 4-6 February, 2019, Dubai, International Organization Center of Academic Research, Istanbul, Turkey, pp. 494-503, ISBN: 978-605-82433-5-4.

Terziev, Venelin. (2019j). The dependence social adaptation- socialization. // INTCESS 2019- $6^{\text {th }}$ International Conference on Education and Social Sciences, 4-6 February, 2019, Dubai, International Organization Center of Academic Research, Istanbul, Turkey, pp. 478-485, ISBN: 978-605-82433-5-4.

Terziev, Venelin. (2019k). Social activity and human resources as social development factors. // INTCESS 2019- $6^{\text {th }}$ International Conference on Education and Social Sciences, 4-6 February, 2019, Dubai, International Organization Center of Academic Research, Istanbul, Turkey, pp. 546-553, ISBN: 978605-82433-5-4.

Terziev, Venelin. (2018). The active model of a social programme and its strategic advantage . // ADVED 2018- $4^{\text {th }}$ International Conference on Advances in Education and Social Sciences Abstracts \& Proceedings, 15-17 October 2018- Istanbul, Turkey, International Organization Center of Academic Research, www.ocerints.org, Istanbul, Turkey, 2018, pp. 189-203, ISBN: 978-605-82433-4-7.

Terziev, Venelin. (2018a). Active social programs development in Bulgaria: contemporary challenges and social management instruments. // ADVED 2018- $4^{\text {th }}$ International Conference on Advances in Education and Social Sciences Abstracts \& Proceedings, 15-17 October 2018- Istanbul, Turkey, International Organization Center of Academic Research, www.ocerints.org, Istanbul, Turkey, 2018, pp. 149-163, ISBN: 978-605-82433-4-7.

Terziev, Venelin. (2018b). Social assistance services and integrated employment in Bulgaria. // ADVED 2018- $4^{\text {th }}$ International Conference on Advances in Education and Social Sciences Abstracts \& Proceedings, 15-17 October 2018- Istanbul, Turkey, International Organization Center of Academic Research, www.ocerints.org, Istanbul, Turkey, 2018, pp. 164-177, ISBN: 978-605-82433-4-7.

Terziev, Venelin. (2018c). Impact of the labor market policies for ensuring employment. // ADVED 2018- $4^{\text {th }}$ 
International Conference on Advances in Education and Social Sciences Abstracts \& Proceedings, 1517 October 2018- Istanbul, Turkey, International Organization Center of Academic Research, www.ocerints.org, Istanbul, Turkey, 2018, pp. 178-188, ISBN: 978-605-82433-4-7.

Terziev, Venelin. (2018d). Importance of human resources to social development. // ADVED 2018- $4^{\text {th }}$ International Conference on Advances in Education and Social Sciences Abstracts \& Proceedings, 1517 October 2018- Istanbul, Turkey, International Organization Center of Academic Research, www.ocerints.org, Istanbul, Turkey, 2018, pp. 204-212, ISBN: 978-605-82433-4-7.

Terziev, V., Georgiev, M. (2018e). A strategic framework for the development of social entrepreneurship in Bulgaria. // Knowledge - International Journal, August 2018, Institute of Knowledge Management, Skopje, Macedonia, 25, 2018, N 1, pp. 23-34, ISSN 1857-923X (for e-version), ISSN 2545 - 4439 (for printed version).

Terziev, V., Georgiev, M. (2018f). Support for the development of social entrepreneurship in Bulgaria. // Knowledge - International Journal, September, 2018, Institute of Knowledge Management, Skopje, Macedonia, 26, 2018, N1, pp.57-74, ISSN 1857-923X (for e-version), ISSN 2545 - 4439 (for printed version).

Terziev, V., E., Arabska. (2014). Assessment of active social policies' impacts on labor market in the Republic of Bulgaria. Kolektivnaya monografiya "Sotsialyno-ekonomicheskie i pravovay razvitiya ekonomiki“, Ufa, Aeterna. Rossiya, 2014. ISBN 978-5-906769-97-8, str. 3-57 (Terziev, V., E. Arabska. (2014). Assessment of active social policies' impacts on labor market in the Republic of Bulgaria. Колективная монография „Социально-экономические и правовы развития экономики“, Уфра, Аэтерна. Россия, 2014. ISBN 978-5-906769-97-8, стр. 3-57).

Terziev, Venelin. (2015). Impact of active social policies and programs in the period of active economic transformations in Bulgaria, „East West” Association for Advanced Studies and Higher Education, Vienna, 2015, ISBN 78-3-903063-44-0, 434 p.

Terziev, Venelin. (2015a). Assessment of active social policies impact of social policies on transformation processes in bulgarian economy, Moscow, 2015, Publisher „Перо“, 110 p.

Terziev, Venelin. (2015b). Opportunities for improving the efficiency of the social adaptation of servicemen discharged from military service in Bulgaria:- Novosibirsk: Publisher CRNS, 2015. ISBN 978-5-00068402-3, $270 \mathrm{p}$.

Terziev, V., E., Arabska. (2016a). Effektivnoe vliyanie na raynok truda posredstvom uluchsheniya realizatsii sotsialynoy politiki. Novosibirsk: Izdatelystvo TSRNS, 2016. ISBN 978-5-00068-496-2, $312 \mathrm{str}$ (Терзиев, В., Е. Арабска. (2016а). Эфффективное влияние на рынок труда посредством улучшения реализации социальной политики. Новосибирск: Издательство ЦРНС, 2016. ISBN 978-5-00068-496-2, 312 стр). 